Studia Anglica Posnaniensia 45/2, 2009

doi: 10.2478/v10121-009-0015-4

\title{
THE ADVICE GENRE (1400-1599). GENRE AND TEXT TYPE CONVENTIONS
}

\author{
IVALLA ORTEGA BARRERA
}

University of Las Palmas de Gran Canaria (CeTIC)

\begin{abstract}
The aim of this paper is to characterize the advice text as a genre in the late medieval and early modern English periods. This genre is very popular during this time and is usually found within medical remedy books. For this reason, it has been generally studied within the scope of medieval recipes in historical discourse analysis. In this paper my intention is to show the independent status of the advice text as a genre. A first step for this lies in the characterization of the linguistic features pertaining to the sections that compound this genre and its comparison with the recipe genre. The corpus for this study has been collected from several sources, both edited and unedited. The description of the text type features will be illustrated with examples taken from this corpus. As I show in the conclusion, the advice text is an independent genre with a clear communicative purpose and addressed to an intended audience.
\end{abstract}

\section{Introduction}

The concepts of genre and text type have been used indistinctively by different scholars (Biber 1988; Görlach 1992; Taavitsainen 2001a: 139; Carroll et al. 2003: 8). For this reason several authors have tried to define them according to specific criteria. Authors such as Taavitsainen (1988 and 2001b) and Pahta (1998), among others, have analyzed the concepts of genre and text type, applying this analysis to different types of texts belonging to the medieval period. Martin (1984), Swales (1987 and 1990), Biber (1988), Devitt (1993 and 2000), Bex (1996) and Moessner (2001), among others, have focused on Present Day English texts. Still, there seems to be much confusion between the two so much so that a recipe is often labelled as a genre and as a text type. Devitt (1993 and 2000), Bex (1996), and Moessner (2001) coincide 
in the fact that the definition of genre is based on external criteria and in that genres are cultural constructs identified by their function and communicative purpose, whereas text types are defined according to internal linguistic features (Biber 1988 and Yw Lee 2001).

One of the clearest definitions of genre is given by Martin (1984: 25) who defines genre as "a staged, goal oriented, purposeful activity in which speakers engage as members of our culture". In this definition genre is related to stages, purpose, audience, activity and to the cultural factors as the external criteria that serve to group texts as genres.

Alonso-Almeida (2008a), following the functional approach to the study of genre, text type and register, also offers a definition of genre and text type when analyzing the Middle English medical charm: "genre is differentiated from text type in the sense that genre is externally defined, whereas text type is characterized according to internal linguistic criteria" (Alonso-Almeida 2008a: 10). He also adds that "[genre] represents the context of culture and how this is manifested in a particular genre in the form of goal oriented stages" (Alonso-Almeida 2008a: 17) following Martin's (1984) definition. This division into goal oriented stages makes us deduct "the type of cultural activity that is expected to be achieved by using the specific texts in a given situational and cultural context" (Alonso-Almeida 2008a: 17). AlonsoAlmeida's claim highlights the importance of the cultural context to determine the stages we find in a genre.

In this paper I shall study the medical advice text as a genre in Middle and Early Modern English by focusing on the stage organization of the texts undersurveyed. I will also present the lexicogrammatical features common to each stage. These characteristics will be analyzed and exemplified using a corpus of texts in a time span of two centuries (1400-1600). In doing so, the following objectives are pursued: (i) to offer the most recurrent linguistic features in the advice text, and (ii) to show the independent status of the advice text as a genre.

The remainder of this paper is structured as follows: section 2 describes the remedy books selected for excerpting the examples of the pieces of advice. A third section presents an analysis of the texts to offer their generic organization and their morphosyntactic features. In the following section, I focus on the distinction between the recipe genre and the advice genre to show the independent status of the latter, while the last section presents the conclusions drawn from this study. 


\section{Data for analysis}

The manuscripts and printed books consulted for this research have been collected from several sources from the medieval and renaissance periods and, all of them, belong to the medical register. They are the following (in square brackets a letter is designated to be used in the examples; for manuscripts a letter and their cataloguing number):

i. Glasgow University Library, Hunter 93, T.4.10 [H93]

ii. A rich store-house or treasury for the diseased Wherein, are many approued medicines for diuers and sundry diseases, which haue been long hidden, and not come to light before this time. Now set foorth for the great benefit and comfort of the poorer sort of people that are not of abilitie to go to the physitions by A. T., practitioner in physicke. Imprinted at London: by Thomas Purfoot for Thomas Purfoot, and Raph Blower, 1596. Bib Name / Number: STC (2nd ed.) / 23606. Copy from: Henry E. Huntington Library and Art Gallery [R]

iii. A verye excellent and profitable booke conteining sixe hundred foure score and odde experienced medicines by Ruscelli, Girolamo. Imprinted at London by Henry Denham, 1569. Bib Name / Number: STC (2nd ed.) / 309. Copy from: Henry E. Huntington Library and Art Gallery [P]

iv. British Library, Sloane100. ff. 27v-29 [S100]

v. British Library, Sloane 989, ff. 10r-21r [S989]

vi. Thys is the myrour or glasse of helth necessary [and] nedefull for euery person to loke in. that wyll kepe theyr body from the sekenes of the pestylence? And it sheweth howe ye planettes reygne in euery houre of the day and the nyght with the natures and exposycyons of the .xii. sygnes, deuyded by the xii. monthes of the yere. And sheweth the remedyes, for many dyuers infyrmytes and dyseases that hurteth the body of man by Moulton, Thomas, 1540?. Imprynted at London: In fletestrete by me Elysabeth [Pickering] late wyfe vnto Robert Redman dwellynge at the sygne of the George nexte to Saynt Dunstones churche, [1541?]. Bib Name / Number: STC (2nd ed.) / 18219. Copy from: British Library [M]

vii. Bodleian Library, Ashmole 396, ff.14r-25r [A396]

viii. Bodleian Library, Rawlinson C.83, ff. 1-8 [C83]

ix. Bodleian Library, Tanner 407 [T407]

A description of the contents of these abovementioned texts from which the pieces of advice have been excerpted for analysis appears in Table 1. In this table Voigts and Kurtz (eVK) electronic catalogue number is given for manuscripts; and for printed books the number of the copy: 
Table 1. Description of the texts used in the analysis

\begin{tabular}{|c|c|c|c|c|c|}
\hline $\begin{array}{c}\text { MS / } \\
\text { Printed } \\
\text { Book }\end{array}$ & Date & Title of texts & Description of texts & $\begin{array}{c}\text { Editor / } \\
\text { author }\end{array}$ & $\begin{array}{c}\text { eVK } \\
\text { no./ } \\
\text { Bib no. }\end{array}$ \\
\hline [H93] & $\begin{array}{l}1550- \\
1570\end{array}$ & $\begin{array}{l}\text { Booke of } \\
\text { Soueraigne } \\
\text { Medicines }\end{array}$ & $\begin{array}{l}\text { Miscellanea. Compilation of } \\
\text { recipes for all kind of ill- } \\
\text { nesses for the head down to } \\
\text { the feet; also recipes to } \\
\text { make waters, oils, and so on }\end{array}$ & Ivalla Ortega & - \\
\hline$[\mathrm{R}]$ & 1596 & $\begin{array}{l}\text { A rich store- } \\
\text { house or treas- } \\
\text { ury for the } \\
\text { diseased }\end{array}$ & $\begin{array}{l}\text { Collection of recipes for the } \\
\text { preparation of medicines } \\
\text { (hidden until this moment) } \\
\text { for different diseases, ad- } \\
\text { dressed to poor people }\end{array}$ & A. T. & 23606 \\
\hline$[\mathrm{P}]$ & 1569 & $\begin{array}{l}\text { A verye excel- } \\
\text { lent and profit- } \\
\text { able book } \\
\text { containing sixe } \\
\text { hundred foure } \\
\text { score and odde } \\
\text { experienced } \\
\text { medicines }\end{array}$ & $\begin{array}{l}\text { Book of medicines for } \\
\text { physic and surgery practiced } \\
\text { by Reverend Master Alexis } \\
\text { in which recipes are pre- } \\
\text { sented }\end{array}$ & $\begin{array}{l}\text { Girolamo } \\
\text { Ruscelli }\end{array}$ & 309 \\
\hline$[\mathrm{S} 100]$ & C15th & $\begin{array}{l}\text { Dietary of } \\
\text { Queen Isabella }\end{array}$ & $\begin{array}{l}\text { Compilation of recipes to } \\
\text { restore health, for the breast, } \\
\text { heart, and also pieces of } \\
\text { advices }\end{array}$ & $\begin{array}{l}\text { Willy Louis } \\
\text { Braekman }\end{array}$ & 7420.00 \\
\hline [S989] & C15th & $\begin{array}{l}\text { Gouernayle of } \\
\text { Helthe }\end{array}$ & $\begin{array}{l}\text { Regimen of health. Informa- } \\
\text { tion on how to follow a } \\
\text { healthier way of life by } \\
\text { practising exercise, by diet, } \\
\text { and containing medicines } \\
\text { for the stomach }\end{array}$ & $\begin{array}{l}\text { Paula Kor- } \\
\text { honen }\end{array}$ & 3251.00 \\
\hline$[\mathrm{M}]$ & 1541 & $\begin{array}{l}\text { Thys is the } \\
\text { myrour or } \\
\text { glasse of helth } \\
\text { necessary } \\
\text { [and] nedefull } \\
\text { for euery } \\
\text { person to loke } \\
\text { in. }\end{array}$ & $\begin{array}{l}\text { Collection of medical reci- } \\
\text { pes and charms to be kept } \\
\text { from the pestilence, includ- } \\
\text { ing other medicines for } \\
\text { different diseases }\end{array}$ & $\begin{array}{l}\text { Thomas } \\
\text { Moulton }\end{array}$ & $1822 \mathrm{a}$ \\
\hline [A396] & C15th & $\begin{array}{l}\text { Secret of } \\
\text { Secretes }\end{array}$ & $\begin{array}{l}\text { Medieval treatise translated } \\
\text { from Arabic in which medi- } \\
\text { cal information about the } \\
\text { preparation of different } \\
\text { medicines to conserve the } \\
\text { health, for sicknesses of the } \\
\text { breast, of the genitals, the } \\
\text { manner of sleeping, diet, } \\
\text { directions for bloodletting, } \\
\text { virtues of some herbs and } \\
\text { stones is presented }\end{array}$ & $\begin{array}{l}\text { Mahmoud } \\
\text { Manzalaoui }\end{array}$ & 2035.00 \\
\hline
\end{tabular}




\begin{tabular}{llllll}
\hline [C83] C15th & $\begin{array}{l}\text { Regimen } \\
\text { Sanitatis }\end{array}$ & $\begin{array}{l}\text { It has to do with the regimen } \\
\text { of health: Regimen Sanitatis } \\
\text { Salernitanum, diet, exercise } \\
\text { and restinga }\end{array}$ & $\begin{array}{l}\text { Mahmoud } \\
\text { Manzalaoui }\end{array}$ & 8067.00 \\
\hline [T407] & C15th & $\begin{array}{l}\text { The Common- } \\
\text { place Book of } \\
\text { Robert Reynes } \\
\text { of Acle }\end{array}$ & $\begin{array}{l}\text { Compilation of knowledge } \\
\text { containing, among others, Cameron } \\
\text { medical recipes, directions } \\
\text { for bloodletting and so on }\end{array}$ & Louis & 2113.00 \\
\hline
\end{tabular}

In the next section, I examine the generic organization of the advice text using the examples taken from the manuscripts and printed books described in Table 1 .

3. Generic organization of the advice text

\subsection{Advice}

A piece of advice is defined as an "opinion given to someone about what they should do in a particular situation" (Longman dictionary 1987), or even as an "opinion given or offered as to action; counsel. spec. medical or legal counsel" $(O E D)$. In the $O E D$, most of the meanings obtainable for the word advice have to do with the piece of advice as an opinion, as we can appreciate in the following entries (the examples taken from them belong to the same period that the texts analyzed in this paper):

a. The way in which a matter is looked at or regarded; opinion, judgment. In this entry, the following examples, belonging to the period studied, are given: 1475 CAXTON Jason $11 \mathrm{~b}$, Me thinketh in myn aduys that the king of Esclauonye doth euyl. 1529 MORE Supplic. Soules Wks. 1557, 334/1 He hath geuen hys aduise therto, and said that they haue to much.

b. Weighing of opinions; consideration, deliberation, consultation, reckoning. To take advice: to deliberate. As an example: 1565 JEWEL Repl. to Harding (1611) 161 Whom vpon verie short aduice, hæ hath condemned.

c. Opinion given or offered as to action; counsel. spec. medical or legal counsel. The example given is: 1413 LYDG. Pylgr. Sowle IV.XXX. (1483) 77 To receyuen goodly goo aduys and counceyll withouten indignacion of herte.

d. Information given, notice; intelligence, news; in $p l$. communications from a distance. spec. in Comm. Formal or official notice from a party concerned. Examples that appear: 1490 CAXTON Eneydos xxii. 82 After wyth this dreme cometh to her aduyse that her cyte and landes of Cartage are all dystroied. 1578 T. N. tr. Conq. W. India 114 These fifteene were spies and..beganne to flie with feare, or else to give advice. 
All these entries deal with the words opinion, consideration, notice or information given. This leads us to think that the advice text expresses a point of view or an idea, but the word advice has another intrinsic or inherent meaning. If we focus on entry number 3 , a new concept appears: a counsel. This new concept adds the intrinsic meaning to the term since a counsel is "an opinion as to what ought to be done given as the result of consultation; aid or instruction for directing the judgement" $(O E D)$. It is an opinion given about what one should or should not do, so it has to do with a subsequent action. In this sense, purpose and intention are also related to the piece of advice; the purpose as the aim which guides action, or the aim to accept the piece of advice to get an objective, and the intention as the determination to act in a certain way, and also the amount of effort to carry out the advice.

\subsection{Advice as a genre}

The pieces of advice can be found in different fields as in cooking or in medicine, among others. In the case of our study, it usually appears embedded in recipes included in remedy books and also in books dealing with health. For this reason it has been generally considered as a recipe and analyzed as such, and not as a different related genre. Only Taavitsainen (2001b: 92) has asserted the independent position of the dietary advice, relating it to the recipe materials and considering it as an overlapping genre. In this study I will follow from here to claim the independent status of the advice as a genre.

Following the definitions of genre given by Martin (1984) and AlonsoAlmeida (2008a), in which genre is externally defined according to goal oriented stages; I will describe the generic organization of the advice genre. Regarding it, the first phase in the analysis is the division of the advice texts into informative stages. The advice text can be divided generically into:

a) Title (TT) that indicates the beginning of the advice texts and their contents,

b) Introductory information (InI) which is generally intended to provide an idea of what the text is about in the absence of a title,

c) Recommendations or directions stage (RoD), which aims at giving a series of indications to be followed or to be avoided in order to be healthy, and, finally,

d) Evaluation or statement of efficacy (E), which gives the result or the consequence of following the recommendations. Diagrammatically, the generic structure potential looks as follows: $(\mathrm{TT})^{\wedge}(\mathrm{InI})^{\wedge}(\mathrm{RoD})^{\wedge}(\mathrm{E})$. 


\subsubsection{Introductory information}

The purpose of the introductory information (InI) is to give an idea of what the text is about, indicating the beginning of the piece of advice and what it is for in the absence of a title or as a complement of it. The piece of advice will inform the reader about what is beneficial or profitable and in other cases it will notify about what is harmful or pernicious for the therapeutic purpose presented. The commonest expressions in InI are, among others, the following:

1) No season of the yere is better than he, neyther profitabler to letting of blode.

(A 396: p.56)

(C83: f.6v)

(C83: f.7)

(C83: f.8)

3) In pis time of wintir conuenient it is

(S989: f.15r)

5) For whi the first and the best is to walk

(S989: f.16)

6) For whi in slepe many superfluytees ben withholde therfor

As these examples show, the introductory information (InI) seems to be connected with the previous text by means of anaphoric devices in the way of transition from a previous genre. In examples (2) and (3) (pis season and in pis time) the demonstrative pronoun pis 'this' indicates a relationship between this introductory information and the previous sentences, indicating the presence of a near related information. In number (1) this reference is indicated by the presence of the pronoun he and in number (4) by using the conjunction and. In examples (5) and (6) the same occurs with the expression for whi. This marks a direct relationship between what has been said previously and what is going to be said. In all of them the author highlights the convenience of doing what is indicated after the InI.

If in the previous examples, from number (1) to number (6), the information given is good or productive to improve health, in the following two instances, numbers (7) and (8), the introductory information contains what is harmful to keep good healthy conditions and so the reader is conveniently alerted against certain unhealthy things:

7) Of the contrarye these dryen, feblen and maken leene the body

8) And ayenwarde pies be pe pingis which chiefly disposith ill and feblith pe body

(C83: f. 8)

In (7) and (8), we find the presence of adjectives and adverbs that imply the transition between information that will improve the reader's condition and information that will deteriorate his health. These discourse markers are of the contrarye, in (7), and ayenwarde in (8), and they represent contrastive information. 
A way to recognize the existence of advice in a text is the possibility of substituting the introductory information by the expressions it is good or it is bad, as in example (8), above, in which the complete sentence can be replaced by bad for the body or it is bad for the body. The same happens in number (4), in which the introductory information can be substituted by it is good for helth and digestion or good for helth and digestion, leading the reader to know that the text presented is a piece of advice.

There are also some introductory information in which the word advice explicitly appears, as in (9) and (10):

9) Moreouer, I will avise

10) He pat schuldyn letyn man or woman blood, hym must (T407: f. 12v) ben avysyd of iiii poyntes

In these instances the scribe has identified his text as an advice, and not as a recipe or a charm, by using this term (avise, avysyd) to refer to them so the terminology related to the genre is included here. In number (9) the adverb moreouer, used as a discourse marker, signals a boundary in the discourse. It adds information to something that has been said before, so the advice gives complementary information. According to Halliday and Hasan's classification of discourse markers (1976: 249), moreover is a complex-emphatic additive discourse marker.

The most frequent words and expressions found in the InI stage are adjectives, most of them in comparative, as profitabler (in (1)), sometimes accompanied by moche the more and moch and ful (in example number (21)); good (example (1)), good in comparative and superlative, as better (in (1)), pe bettir and the best in examples (4) and (5) respectively. All these instances show the author's need to qualify the information given. At variance with this, in those InI sections in which the author wants to emphasize that what he is going to say is bad for the health, the adjectives and verbs used are dryen, feblen and maken leene (example (7)), or ill and feblith (in (8)). These adjectives and verbs utter that the data that will follow them is not good for the health, representing negative characteristics.

The introductory information found in books dealing with health, as in all the previous instances analyzed, is not visually identifiable; it is inserted in the running text to introduce the topic of the text it is in, or to mark the transition from a previous recipe. This is a clear difference between the introductory information and the title stage, which will be studied in the following section. 


\subsubsection{Title}

The title (TT) appears at the beginning of the advice text and it indicates the contents of the text, comprising the same function as the InI section, but being different visually and structurally.

The InI section, as explained above, is embedded in the running text as an integral part. The TT stage, on the contrary, is visually identifiable because it appears in a separate line preceding the piece of advice. The TT section is used in recipe books, following the same pattern that the recipes included in these books. Some examples of titles are given below:

11) Good for the stomack

12) Ill for the sight

13) It is good for you

All these instances present a TT whose structure is adjective + a purpose phrase introduced by for, that is, a for-purpose noun phrase, and all of them appear in a separate line, as the titles for recipes. Thus, instances (11) and (13) give information about what the reader should do to improve or restore the health, whereas number (12) offers information about what the reader should avoid.

\subsubsection{Recommendations or directions}

After the title or the InI stage, there is another section called recommendations or directions (RoD) in which the author gives a series of indications to be followed or to be avoided in order to improve the healthy condition. These recommendations are listed and they all present the same syntactic structure, that is, an infinitive of purpose (to + infinitive verb + complement (noun phrase)), as in the following examples:

14) No seson of the yere is better than he, neyther profitabler to letting of blode. It is not bad to vse women ther-yn, so it be not ayenst the lawe, and to meve pe body, and to lose the wombe, to entre and vse bathes and swetis, to drynke spices for digestion.

(A396: f. 18v)

15) A Rule to knowe what thinges are good and holosome for the Braine. 


$$
\begin{aligned}
& { }_{++}^{++}{ }_{+}^{+}{ }_{+}^{+}+{ }_{+}^{+}+{ }_{+}^{+}+{ }_{+}^{+}+
\end{aligned}
$$

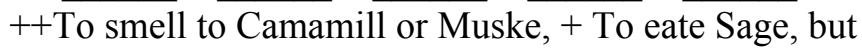

$$
\begin{aligned}
& \left\{\begin{array}{l}
\text { not ouermuch, }+ \text { To drinke Wine measurablie, }+ \text { To } \\
\text { keepe the Head warme, }+ \text { To washe your Hands often }
\end{array}\right. \\
& \text { + To walke measurablie, }+ \text { To sleepe measurablie, }- \\
& + \text { To heare litle noise of Musicke or singers, }+ \text { To eate } \\
& \left\{\begin{array}{l}
\text { Mustarde \& Pepper, }+ \text { To smell the sauour of Red-roses, } \\
\& \text { to washe the Temples of your Heade often with Rose- }
\end{array}\right.
\end{aligned}
$$

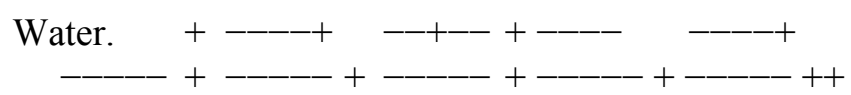

In both instances, there is a prevalence of the infinitive of purpose structure in the RoD section: to vse women ther-yn, to meve pe body, to lose the wombe... in example (14), and to smell to Camamill or Muske, to eate Sage, to drinke Wine measurablie... in (15). Sometimes an explanation is offered after the complements as in number (14) so it be not ayenst the lawe, in which the scribe asserts that the reader can do what he has said if it is not prohibited by law, or in (15) but not ouermuch, in which the scribe adds that the person should not eat too much Sage avoiding an excess.

All the indications or recommendations are separated by a comma or by using the conjunction $a n d^{1}$. In the case of number (15), a symbol (+) denotes the beginning of each direction ${ }^{2}$, making them visually identifiable as To drinke Wine measurablie, + To keepe the Head warme, + To washe your Hands often $+\ldots$, following this structure till the last direction. Sometimes, there is ellipsis of the and conjunction but it can be easily retrieved from the context, as can be seen in number (14): and to meve pe body, and to lose the wombe, to entre and vse bathes and swetis, to drynke spices for digestion. In this instance, the ellipsis of the and conjunction appears before two sentences: to entre and vse bathes and swetis and to drynke spices for digestion.

There are some cases in which the infinitive of purpose (to + infinitive verb + noun phrase) structure is omitted, as in (16):

\footnotetext{
1 Alonso-Almeida (2008b) has studied the presence and value of and conjunctive in Middle English medical recipes.

2 For more information about this type of structure-signalling devices see Alonso-Almeida (2005-2006: 327-342).
} 
16) This is good for be brest/ Clarified hony and clene. sugre cassyn. Pat is caphatyn. and candi. buttir esily saltid. licoris in al= le maner uss. To use anyse seed. Datis mesurably. ffigis rostid. and namely olde figes. ysope in al maner. horhowne in drynkis.

buttir of almaundis. to be anoyntid withawte/

(S100: f. 29v)

In (16) there is an asyndetic sequence of to-infinitive structures although we can also find the absence of this structure easily retrieved from the context. In this example when we have a list of ingredients: clarified hony, sugre cassyn, butter, we can infer the following meaning: to eat, drink or use clarified hony, sugre cassyn, buttir. All the recommendations appear separated by a punctuation mark (a comma or a stop).

In the RoD section, some verbs as eat, hear, walk, drink, use, sleep, labour, stand, and wash, among others, are repeated. They are all related to daily human activities such as resting, exercise and diet, epitomizing the precepts in the Regimen Sanitatis Salernitanum for having good health.

\subsubsection{Evaluation or efficacy sentence}

The last section found in the pieces of advice is the evaluation or efficacy sentence (E), studied by Jones (1998), and Alonso-Almeida and Cabrera-Abreu (2002) for the recipe. It is an optional stage since it does not appear in every piece of advice. This section establishes the end of the piece of advice and the effectiveness of following the recommendations given by the author, as seen in examples number (17), (18), and (19):

17) All these and many other dryen

(A396: f. 20r) and feblen the body.

18) pies be such ping pat bringith a man soone to grete sikenes and febilnes of body and soone to his ende.

19) And it maketh your eyes well to digest.

In the examples (17) and (18), the author concludes by claiming that the person should avoid what he has said previously to be healthy; and in number (19) the author argues that if the ill person follows the recommendations 
given, he or she will get the like effect. They all present the same structure, that is, a simple sentence whose verb is in the present tense (dryen, feblen, bringith, maketh).

All the pieces of advice analyzed present the same internal structure. Sometimes, we can find a piece of advice where the author presents the information about what is profitable followed by the information about what is harmful for the same cause. The introductory information or the title will separate both pieces of advice. To illustrate this (notation of stages is given in square brackets):

20) A vomyte also wassheth the body and purgeth the stomak of all bad humours and putrified. And whan fewe humours be in the stomak the hete is comforted forto digest and forto dewe the body and yeve it humydite and fatnesse. And moche the more and profitabler [INI] yf he be mery and glad, and yf he myght have reasonable glory and honoure, and of his enemyes victorye, hope and trust in the peple, in pleyes and sightes to delyte, to se faire faces and visages, and beholde delitable bokes, and to here swete songes and delitable, to laugh amonge tham that loven hym, to be clad in the best clothyng of colour and teyntour, and to be wele an-oynted with the best according oynementis to the tyme. [ROD] Of the contrarye these dryen, feblen and maken leene the body: [INI] to ete and drynk lytell, labour off, and to moche stoned in the sone, with-out mesure walke, slepe before mete vpon hard beddes, to be vexed in mynd, to entre bathes there as sulphure water is, and sitte longe ther-yn, vse ete drye, salt, and resty mete, and to drynke full olde wyne off, to take and make many seeges, oft to lette blode and to lak mesure ther-in, to be to besy in venerien actis, to be vexed with bad thoughtes, to have drede oft and sorrow. [ROD] All these and many other dryen and feblen the body. [E]

(A396: f. 20r)

In this example, the author presents first the piece of advice to be healthier and then the piece of advice that offers the things that must be avoided for the same purpose. Another illustration of this (notation of stages is given in square brackets):

21) Good for the sight [TT]

Take redrose, ffennell, vervyn rootes, salendyne, eufras, pimpernell, occulus xpium, to wash your eyes with cleane water, To looke vpon green colours, measurable sleepe, to looke on a faire glasse much, often washing of your hands and ffeet, [ROD] and it maketh your eyes well to digest. [E]

(H93: 84) 


\section{2) Ill for the sight [TT]}

To studdy after meat, and wynes, Onyons, Leekes and Lettice, too suddaine going after meat, wynds, hott ayre, and cold ayre, Dronkennesse, Gluttonie, Milke, Cheese, much beholding of bright things, and aswell redd things as white, Musterd, much sleepe after meat, too much walking after meat, and too much letting of blood, Colewortes. Incontinencie, fire, dust, too much weeping, and ouermuch watching. [ROD]

(H93: 84)

In these instances, the author presents the beneficent things for the sight first and then the damaging things for it. Here, the information appears separated into two different paragraphs and we have also a recipe embedded in number (21) beginning with take, as expected (Alonso-Almeida 1998-1999; Taavitsainen 2001b): Take redrose, ffennell, vervym rootes, salendyne, eufras, pimpernel, occulus xpium. The rest of these two examples offer the characteristic structure: TT and RoD. As an optional stage we find the E section in (21): and it maketh your eyes well to digest. Both pieces of advice present different information, but they both coincide in that they are for the same disease (sight).

In number (20) the use of the conditional is an innovation in the INI section. The use of if-sentences shows some kind of selection because the person who is going to follow the advice must have a series of specific personal characteristics that seem to be related to knights as mery and glad, and yf he myght have reasonable glory and honoure, and of his enemyes victorye, hope and trust in the peple.

In the ROD section, the recommendations given are related to the person's humour, to the physical appearance and to some cultural aspects following the expected structure (to-infinitive of purpose) as to se faire faces and visages, and beholde delitable bookes, and to here swete songes and delitable, to be clad in the best clothyng of colour and teyntour. Following Alonso-Almeida and Carroll's (2004: 31) classification of Middle English medical texts, the advice texts appear in practice-only books.

Another example is presented in (23), where the advice texts are visually identifiable because they appear in two columns flanked by brackets: 
In the example above, excerpted from a recipe book (A rich store-house or treasury for the diseased), the author has outlined the information of the advice texts in two columns between brackets, one for the things which are good for the sight, and another one with the things that are bad for the sight, in a sort of schema. Thus, each recommendation is visually separated, each occupying one line, maybe as an easier and quicker way to be recognized by the reader. This presentation allows the reader to identify and check what he must do or avoid to improve his health. There is also an asyndetic sequence of to + infinitive and the absence of the same structure in some lines, as we have explained before.

In short, the presence of these three sections and the lexico-grammatical features that define them makes the advice be an independent genre, separating it from the recipe, as we will analyze in the following section.

\section{Advice and recipe texts}

After the description of the structure of the advice genre, I will pay attention to the differences and similarities between this genre and the recipe. Until now, the pieces of advice have not been studied as a different genre, instead they have been considered as recipes or a section in recipes because they appear embedded in remedy books or in books dealing with health. They also share a same visual aspect with recipes and both, the recipes and the advice texts, have a similar communicative purpose, that is, they have been written for restoring or 
keeping health. Alonso-Almeida (1998-1999), in his study on texts dealing with women's illnesses, has identified a set of recommendations within recipes given by the authors of these texts, calling them further therapeutic information. This information is a section belonging to the recipe text and should not be confused with the advice text.

The first thing that distinguishes recipes from advice texts as different genres is their internal structure. While the recipes can be divided into title (TT), ingredients (I), preparation (P), application (A) (use, dosage and duration), and evaluation of treatment ${ }^{3}$ (E) as the main stages, the advice texts only present four different sections, one of them being optional: title, introductory information, recommendations or directions and evaluation or efficacy sentence, as shown in section 3.2. above. Each stage has a definite purpose and different linguistic features that I will analyze on the following examples (stages appear in square brackets):

\section{4) Ffor the same $[\mathrm{TT}]$}

Take a browne bread toast and a quantitie of black sope. [I] And spread it on the toast like butter. And putt it in a lynnen cloth for raying of your geare. [P] And lay it hott to your greife. [A] And it shall doe you much good by the helpe of God. [E]

(H93: 214-215)

In this instance, we can appreciate a recipe sample with all its generic stages. The title is ffor the same, which makes reference to a previous recipe text. This shows cohesiveness in the text since the reader must read back to a previous part of the text to know which illness the text refers to. After the title we find the ingredients section: Take a browne bread toast and a quantitie of black sope, then the preparation stage: And spread it on the toast like butter ... raying of your geare, the application And lay it hott to your greife, and finally the evaluation of the treatment And it shall doe you much good by the helpe of God. Each stage has a different content and function as shown by functional labelling: the title presents what the recipe is for, the ingredients section gives the material needed to prepare the remedy, the preparation section indicates the way in which the reader must prepare the remedy, the application section establishes the dosage, use and time the remedy must be applied, and the evaluation of the treatment validates the efficacy of the remedy. Another characteristic found in this example is the use of the second person singular pronoun (you) as a direct reference to the reader.

Alonso-Almeida $(1998,1999)$ has analysed the stages presented in recipes establishing the purpose and the lexico-grammatical features of each section. 
As for the language, consider also (25) below to compare with (24) above (stages are offered in square brackets):

25) Another for the same. [TT]

IT helpeth the Disenteria, [INI] to drinke the iuice of Sorell with

Wine, and the iuice of Marshe Mallowes also beeyng

drunke doeth like effect. To drinke also in the mornyng fa=

styng three ounces of Borage water, helpeth the saied disease:

also it helpeth with more efficacie to drinke the iuice of Bursa

Pastoris. [ROD]

In this example of the advice, there is no any visual difference with number (24). Number (25) also presents a first line as a title with the use of another for the same as an anaphoric reference. However, after this title, we find all the stages belonging to the pieces of advice as the InI section: IT helpeth the Disenteria, and all the recommendations: to drinke the iuice of Sorell with Wine, and the iuice of Marshe Mallowes ... the iuice of Bursa Pastoris. In this section the juice of Bursa Pastoris is presented as the best remedy to be used. Thus, the cohesiveness in the text is shown by the presence of saied disease, that is an anaphoric reference.

The linguistic devices found in both genres are different. Each stage belonging to each genre presents a set of internal linguistic features that characterize them. In the case of the recipe, Görlach (1992) established a series of characteristics in his study about the cooking recipe. The main internal linguistic features of each genre are offered in Table 2:

Table 2. Main linguistic features of recipes and pieces of advice

\begin{tabular}{|c|c|}
\hline Recipe & Advice \\
\hline $\begin{array}{l}\text { Massive use of imperatives (take, } \\
\text { spread, put, lay) }\end{array}$ & $\begin{array}{l}\text { Use of to-infinite of purpose struc- } \\
\text { ture }\end{array}$ \\
\hline $\begin{array}{l}\text { Use of the second person singular } \\
\text { pronoun (you, your) }\end{array}$ & $\begin{array}{l}\text { Absence of the second person singu- } \\
\text { lar pronoun/He occurs occasionally. }\end{array}$ \\
\hline $\begin{array}{l}\text { Use of and conjunction to show } \\
\text { mainly temporal and result meanings. }\end{array}$ & $\begin{array}{l}\text { Use of paratactic and conjunction to } \\
\text { show addition }\end{array}$ \\
\hline $\begin{array}{l}\text { Vocabulary: herbs, culinary terms, } \\
\text { measures }{ }^{4} \text {, verbs related to applica- } \\
\text { tion (eat, drink, give, do), and cook- } \\
\text { ing verbs (frye, boil) }\end{array}$ & $\begin{array}{l}\text { Vocabulary: resting (sleep), diet } \\
\text { (drink, eat) and exercise (walk). } \\
\text { Some herbs and culinary terms (Bo- } \\
\text { rage, wine) }\end{array}$ \\
\hline
\end{tabular}

$4 \quad$ For more information see Görlach (1992), Alonso-Almeida (1998-1999, 2000), and Carroll (1999, 2004). 
Lexically, the words used in both genres are determined by the topic, and hence they may present similar content words as seen in Table 2 . It leads us to think that they are related genres because of the presence of related vocabulary and the goal they pursue: in the case of recipes, to give information about a procedure to cure an illness or to improve the health, and in the case of the pieces of advice, to give information to improve the health or for not to deteriorate the health. Thus, the integration of the advice genre in the recipe could be such as to appear together, as in example (26):

26) An excellent good drinke to be taken euery morning for a preseruatiue against the Plague,

and for to auoide infection.

TAke a handfull of Winter-Sauery, and boyle the same in a quart of good wine-Vinegar, with a spoonefull of Graines being very fine beaten, and put into the same, then put into it a quantity of fine Suger, and so drinke a good draught thereof euery morning fasting.

*When you must of necessitie come into any place where any infectious persons are, it is good for you to smell to the root of Angellica, Gentian, or Valerian, and to chew any of these in your mouth.

(R: f. 64r)

In this example, the advice genre appears after the recipe. Visually speaking, the advice seems to be part of the recipe although the presence of the asterisk indicates that it is not. The title of the recipe is: An excellent good drinke to be taken euery morning for a preseruatiue against the Plague, and for to auoide infection. Then we have the ingredients and the preparation stage mixed: TAke a handfull of Winter-Sauery, and boyle the same in a quart of good ... of fine Suger, and at the end we have the application: and so drinke a good draught thereof euery morning fasting.

After the recipe and preceded by the asterisk, we have the advice. The author has used this convention to signal its beginning, being conscious of the presence of a different genre. The new text thus is easily identifiable from the rest. It starts with the InI section: When you must of necessitie come into any place where any infectious persons are; the TT stage: it is good for you, and then the RoD section appears: to smell to the root of Angellica, Gentian, or Valerian, and to chew any of these in your mouth, as expected.

\section{Conclusion}

To conclude, the present study has considered the advice text as a genre. It appears in remedy books or in books dealing with health and presents some rec- 
ommendations to be followed by the reader either to improve their health or not to deteriorate his/her present health state. This genre has not been linguistically studied until now, surely because of the scarcity of samples, or because they were usually studied as recipe sections.

This study has revealed that the advice genre is independent from other related genres, mainly the recipe one. Although sometimes they are visually similar, they are structurally, formally and functionally different.

Structurally, the advice genre presents a well-defined internal structure that divides into four different stages (InI, TT, RoD and E) that are completely different to those that conform the recipe genre (title, ingredients, preparation, application and evaluation). Formally, they do not share the same linguistic features. While the advice genre is characterized by the use of the to-infinitive of purpose structure and the absence of the second person singular pronoun, the recipe genre is distinguished by a massive use of imperatives and the use of the second person singular pronoun as the main linguistic features.

As for lexis, both genres share the use of vocabulary related to herbs and culinary terms. The difference that exists between them is that the recipe genre uses vocabulary dealing with herbs, animals, culinary terms, and measures whereas the advice genre makes use of vocabulary related to the Regimen Sanitatis Salernitanum, that is, vocabulary referred to resting, diet and exercise.

Functionally, they pursue a different goal. The main goal of the recipe genre is the making of some product to restore health whereas the main goal of the advice is to keep good healthy condition.

The conclusion drawn from this analysis reveals that the advice is a genre in itself, but the very nature of this genre allows for occurrence and embedding in other genres for medical purposes, such as recipes or larger academic treatises.

\title{
REFERENCES
}

\author{
Alonso-Almeida, Francisco - Mercedes Cabrera Abreu \\ 2002 "The formulation of promise in Medieval English medical recipes: A relevance- \\ theoretic approach", Neophilologus 86: 137-154. \\ Alonso-Almeida, Francisco - Ruth Carroll \\ 2004 "A new proposal for the classification of Middle English medical texts", in: Alicia \\ Rodríguez-Álvarez - Francisco Alonso-Almeida (eds.), 21-34. \\ Alonso-Almeida, Francisco \\ 1998-1999 “'Gyf hyr this medycyn': Analysing the Middle English medical recipe discourse”, \\ Revista de Lengua para Fines Especificos 5/6: 15-46. \\ 2000 Edition and study of a late Medieval English medical receptarium. G.U.L. MS Hunter \\ 185 (T.8.17). [Unpublished Doctoral Dissertation, University of Las Palmas de Gran \\ Canaria, Spain.]
}


2005-2006 "Structure-signalling devices in Middle English manuscripts on the diseases of women", Boletín Millares Carlo: 327-342.

2008a "The Middle English medical charm: Register, genre and text type variables", Neuphilologische Mitteilungen 109/1: 9-38.

$2008 \mathrm{~b}$ "The pragmatics of and-conjunctives in Middle English medical recipes: A relevance theory description”, Journal of Historical Pragmatics 9/2: 171-199.

Bex, Tony

1996 Variety in written English. London: Routledge.

Biber, Douglas

1988 Variation across speech and writing. Cambridge: Cambridge University Press.

Brinton, Laurel J.

1996 Pragmatic markers in English. Grammaticalization and discourse functions. Berlin: Mouton de Gruyter.

Carroll, Ruth

1999 "The Middle English recipes as a text-type", Neuphilologische Mitteilungen 100: 27-42.

2003 "Recipes for laces: An example of a Middle English discourse colony", in: Risto Hiltunen - Janne Skaffari (eds.), 137-165.

2004 "Middle English recipes: Vernacularisation of a text-type", in: Irma Taavitsainen Päivi Pahta (eds.), 174-191.

Christie, Frances (ed.)

1984 Children writing: Reader. Geelong: Vic.

Culpeper, Jonathan

1996 "Towards an anatomy of impoliteness", Journal of Pragmatics 25: 349-367.

Devitt, Amy J.

1993 "Generalizing about genre: New conceptions of an old concept", College Composition and Communication 44/4: 573-586.

2000 "Integrating rhetorical and literary theories of genre", College English 62/6: 696-718. Voigts, Linda - Patricia Kurts

2000 Scientific and medical writings in Old and Middle English: An electronic reference [CDROM]. Ann Arbor: Michigan University Press.

Görlach, Manfred

1992 "Text-types and language history: The cookery recipe", in: Matti Rissanen - Ossi Ihalainen - Terttu Nevalainen - Irma Taavitsainen (eds.), 736-761.

Halliday, Michael - Ragib Hasan

1976 Cohesion in English. London: Longman.

Jones, Clair

1998 "Formula and formulation: 'Efficacy phrases' in Medieval English medical manuscripts", Neuphilologische Mitteilungen 99/2: 199-209.

Jucker, Andreas H. (ed.)

1995 Historical pragmatics. Pragmatic developments in the history of English. (Pragmatics - Beyond New Series 35). Amsterdam: John Benjamins.

Longman dictionary

1987 Longman dictionary of contemporary English. (2 ${ }^{\text {nd }}$ edition.) Harlow: Longman Group.

Martin, James

1984 “Language, genre and register", in: Frances Christie (ed.), 21-29. 
Moessner, Lilo

2001 "Genre, text type, style, register: A terminological maze?", European Journal of English Studies 5/2: 131-138.

Östman, Jan-Ola - Brita Wårvik

1994 "The Fight at Finnesburh: Pragmatic aspects of a narrative fragment", Neuphilologische Mitteilungen 95/2: 207-227.

Pahta, Päivi

1998 Medieval embryology in the vernacular: The case of De spermate. (Mémories de la Société Neophilologique de Helsinki 53.) Helsinki: Société Neophilologique.

Rissanen, Matti - Ossi Ihalainen - Terttu Nevalainen - Irma Taavitsainen (eds.)

1992 History of Englishes: New methods and interpretations in historical linguistics. Berlin and New York: Mouton de Gruyter.

Rissanen, Matti - Merja Kytö - Kirsi Heikkonen (eds.)

1997 English in transition. Corpus-based studies in linguistic variation and genre styles. Berlin: Mouton de Gruyter

Simpson, John A. - Edward S. C. Weiner (eds.)

1989 The Oxford English dictionary $(O E D)$. ( $^{\text {nd }}$ edition.) Oxford: Oxford University Press, available at http://dictionary.oed.com.

Swales, John

1987 "Utilizing the literatures in teaching the research paper", TESOL Quarterly 21/1: 4168.

1990 Genre analysis. Cambridge: Cambridge University Press.

Taavitsainen, Irma

1988 Middle English lunaries. A study of the genre. (Mémoires de la Société Néophilologique de Helsinki XLVII.) Helsinki: Société Néophilologique.

1997 "Genre conventions: Personal affect in fiction and non-fiction in Early Modern English", in: Matti Rissanen - Merja Kytö - Kirsi Heikkonen (eds.), 185-266.

2001a "Changing conventions of writing: The dynamics of genres, text types, and text traditions", European Journal of English Studies 5/2: 139-150.

$2001 \mathrm{~b}$ "Middle English recipes: Genre characteristics, text type features and underlying traditions of writing", Journal of Historical Pragmatics 2/1: 85-113.

Taavitsainen, Irma - Päivi Pahta (eds.)

2004 Medical and scientific writing in late Medieval English. Cambridge: Cambridge University Press.

Yw Lee, David

2001 "Genres, registers, text types, domains, and styles: Clarifying the concepts of navigating a path through the $B N C$ jungle", Language Learning and Technology 5/3: 37-72. 